$\underline{\xi}=-m$

\title{
Immunological status in broiler chickens vaccinated with newcastle vaccine and treated with cephradine
}

\author{
Ashraf Elkomy ${ }^{1}$, Mohamed Aboubakr ${ }^{*}$, Faten Elsayed ${ }^{1}$, Elsayed Emam², Mohammed Kassem $^{3}$ \\ ${ }^{1}$ Pharmacology Department, Faculty of Veterinary Medicine, Benha University, 13736, Moshtohor, Toukh, Qalioubeya, Egypt \\ ${ }^{2}$ Animal Health Research Institute (Zagazig branch), Egypt. ${ }^{3}$ Elanco Animal Health, New Cairo Egypt \\ *Corresponding author E-mail: mohamed.aboubakr@fvtm.bu.edu.eg
}

\begin{abstract}
The objective of this study is to clarify the effect of cephradine on cellular and humeral immune responses in broiler chickens. One hundred one-day-old Hubbard broiler chicks were divided into four equal groups ( 25 chicks in each). 1st group healthy broiler chickens nonvaccinated non medicated (control group), $2^{\text {nd }}$ healthy broilers vaccinated with Newcastle vaccine only, $3^{\text {rd }}$ group healthy broilers received $20 \mathrm{mg}$ cephradine in drinking water daily for 5 consecutive days and $4^{\text {th }}$ group healthy broilers vaccinated and received $20 \mathrm{mg} / \mathrm{kg}$ b.wt cephradine daily for 5 consecutive days. At $1^{\text {st }}, 10^{\text {th }}$ and $20^{\text {th }}$ day post administration, blood samples were collected for determination total and differential leucocytic count, phagocytic activity, index, killing percentage and HI titer. Vaccinated broilers by Newcastle disease virus vaccine only, showed insignificant increase in leukocytic count, lymphocyte, heterophils, nitric oxide, lysozyme activity, total protein, total, $\gamma$ globulin and HI titers at 1 st day post vaccination. Beside significant increase at $10^{\text {th }}$ and $20^{\text {th }}$ day post vaccination coupled with insignificant increase in eosinophils, basophils, monocyte, phagocytic activity, phagocytic index, killing $\%$, albumin and $\alpha$ globulin and non-significant decrease in serum $\beta$ globulin and $\mathrm{A} / \mathrm{G}$ ratio allover experimental periods post vaccination. Broilers received cephradine and/or vaccinated with Newcastle vaccineeither alone or together, showed insignificant increase in leukocyte, heterophils, lymphocyte, eosinophils, basophils, monocyte, nitric oxide, lysozyme activity, total protein, albumin, total, $\alpha, \beta, \gamma$ globulin, A/G ratio throughout experimental period post vaccination. Beside significant decrease in phagocytosis, phagocytic index and killing $\%$ at $1^{\text {st }}$ day and insignificant decrease at $10^{\text {th }} \& 20^{\text {th }}$ day post vaccination coupled with significant decrease in HI titers at 1 st day post administration and insignificant decrease at $10^{\text {th }} \& 20^{\text {th }}$ day post vaccination. It was concluded that vaccination by Newcastle disease virus vaccine induced immune-stimulant but cephradine provoked a remarkable immunosuppressive effect in broiler chickens. Therefore, vaccination not recommended during treatment by cephradine.
\end{abstract}

Keywords: Broiler chickens; Cephradine; Immunity; Vaccine.

\section{Introduction}

Antibiotics are important tool in reducing avian diseases. Antibiotics are extensively used as productivity enhancers in poultry production to control infectious diseases (Moreno et al., 2007). Immunosuppression properties of some antibiotics are effective in inhibition of both cellular and humoral immune responses to a variety of vaccines (Shalaby, 1989). Several antibiotics suppress the immune response by their ability to interfere with protein or immunoglobulin synthesis (Richard and Merle, 1984).

Cephalosporins are a group of antibiotics derived from mould of cephalosporium spp. and are based on 7-aminocephalosporic acid which corresponds to 6-penicilanic acid in penicillin (El-Hewaity et al., 2014). Cephradine is a beta-lactam, first-generation cephalosporin antibiotic with bactericidal activity and available in both oral and parenteral dosage forms (Wilson and Gisvold, 1982). Cephradine have a good activity against $\mathrm{Gr}+$ ve bacteria and relatively moderate activity against some enterobacteria, including strains of E coli, K. pneumonia, Proteus mirabilis, Salmonella and Shegella species (James, 1993). Antibacterial activity due to ability of beta-lactamase ring to bind bacterial enzyme Transpeptidase which important for proper cell wall synthesis (Thomson et al., 1984; El Sayed et al., 2016; Aboubakr and Elbadawy, 2017). The present work was planned to investigate the effect of cephradine inducing immuno-suppressive effect on broilers vaccinated with Newcastle virus vaccine.

\section{Materials and methods}

\subsection{Drugs}

Cephradinee (Atocef Forte) ${ }^{\circledR}$ Water-Soluble Powder Each 100 gm of powder contain 20 gm cephradine base. It is available as package containing $500 \mathrm{gm}$. It is produced by ATCO Pharma Company, Egypt. 


\subsection{Experimental broiler chickens}

One hundred apparently healthy one day old Hubbard broiler chicks obtained from Cairo Poultry Company (CPC) were used in the present study. Chicks were floor reared under hygienic measures. Chicks were fed on balanced commercial ration free from any medications from Cairo Poultry Comp and water provided ad-libitum.

\subsection{Newcastle vaccine}

Avipro ${ }^{\circledR}$ Polybanco (Live Vaccine against Newcastle-Bronchitis B1 Type, B1 Strain, Mass. \& Conn) Manufactured by Elanco animal health Co. was used as eye drops for vaccination of chicks on the $7^{\text {th }}$ day of age against Newcastle disease. Avipro ${ }^{\circledR}$ ND-chick (Killed Newcastle disease virus, B1 type, Lasota strain produced by Elanco Co.) given SC. at $7^{\text {th }}$ day old

\subsection{Experimental design}

One hundred one-day-old Hubbard broiler chicks were divided in to four equal groups ( 25 chicks in each). $1^{\text {st }}$ group healthy broilers nonvaccinated non medicated served as control, $2^{\text {nd }}$ group healthy broilers vaccinated with Newcastle disease virus vaccine only, $3^{\text {rd }}$ group healthy broilers received $20 \mathrm{mg} / \mathrm{kg}$ b.wt cephradine in drinking water daily for five consecutive days and $4^{\text {th }}$ group healthy broilers vaccinated with Newcastle disease virus vaccine and received cephradine in same dose and period. At $1^{\text {st }}, 10^{\text {th }}$ and $20^{\text {th }}$ day post injection two blood samples was collected from wing vein. First sample was collected in test tub contain EDTA as anticoagulant for estimation total and differential leucocytic count according to Jain (1986). Phagocytic activity, Phagocytic index and killing \% were determined according to Rouse et al., (1980) and Woldehiwet and Rowan (1990), respectively. Second sample was collected in test tub for obtain clear serum for estimation of serum total protein according to Doumas et al., (1981), protein fractions were performed by electrophoresis test (Henry et al., 1974). Nitric oxide (Rajarman et al., 1998; Ramadan and Attia, 2003) and lysozyme activity (Schltz, 1987).

Tissue specimens from the internal organs (liver, kidneys, Bursa of fabricious \& spleen) of all groups were collected and immediately fixed in $10 \%$ neutral buffered formalin for pathological study according to Lillie and Fulman (1976).

\subsection{Statistical analysis}

Obtained data was analyzed according to Petrie and Watson (1999).

\section{Results}

Vaccinated broilers with Newcastle vaccine only showed insignificant increase leukocytic count, lymphocyte, heterophils, nitric oxide, lysozyme activity in total protein, total, $\gamma$ globulin and HI at $1^{\text {st }}$ day post vaccination beside significant increase at $10^{\text {th }}$ and $20^{\text {th }}$ day post vaccination. Coupled with insignificant increase in eosinophils, basophils, monocyte, phagocytic activity, phagocytic index, killing \% , albumin and $\alpha$ globulin and non-significant decrease in $\beta$ globulin and $\mathrm{A} / \mathrm{G}$ ratio allover experimental periods post vaccination.

Chickens received Cephradine and/or vaccinated received cephradine, showed insignificant increase in leukocyte, heterophils, lymphocyte, eosinophils, basophils, monocyte, nitric oxide and lysozyme activity, total protein, albumin, total, $\alpha, \beta, \gamma$ globulin, A/G ratio allover experimental period post vaccination beside significant decrease in phagocytic activity, phagocytic index and killing $\%$ at $1^{\text {st }}$ day coupled with insignificant decrease at $10^{\text {th }}$ and $20^{\text {th }}$ day post vaccination coupled with significant decrease in HI titers at 1 st day post administration and insignificant decrease at $10^{\text {th }}$ and $20^{\text {th }}$ day post administration.

Plate (1) Liver (fig 1, 2 \& 3) of broiler chickens vaccinated with Newcastle vaccine showed moderate degenerative changes in hepatocytes, mostly hydropic, moderate infiltration of the portal area with heterophiles and lymphocytes beside disorganization of the hepatic cells. Kidney (fig 4) sections revealed hypo-cellularity and atrophy of the glomeruli and degenerative changes in moderate no. of the renal tubules. Bursa of fabricious (fig 5) showed mild depletion of follicular lymphocytes. Spleen (fig 6) showing congestion of splenic sinusoids and depletion of some follicular lymphocytic.

Plate (2) Liver $(1 \& 2)$ of broiler vaccinated and received cephradine showed normal parenchyma, however. Some sections showed portal aggregations of heterophils and lymphocytes. Kidney ( $3 \& 4)$ showed edema within renal papillae beside lymphocytic infiltration, some sections revealed hydropic degeneration in both glomerular and renal tubular epithelium. Bursa (fig 5 and 6) showed normal mucosa and bursal follicles. Some examined sections showed atrophy of some lymphocytic follicles beside edema with mild cystic changes in both the follicles and the mucosal lining. Some sections of spleen (fig $7 \& 8$ ) showed apparently normal splenic structures, others showed mild to moderate lymphocytic depletion of both white and red pulp. Mild infiltration of heterophiles was also seen in the splenic sinusoids.

\section{Discussion}

Our results revealed, vaccinated broilers with Newcastle vaccine only showed insignificant leukocytosis, lymphocytosis and heterophiliaat $1^{\text {st }}$ day and significant increase at $10^{\text {th }}$ and $20^{\text {th }}$ day post vaccination beside non-significant eosinophilia, basophilia and monocytosis allover experimental period post vaccination. Similar results were obtained by Wang et al., (2015) who reported that insignificant effect on leukocytic count heterophils, lymphocte in chickens post using Newcastle vaccine. Newcastle vaccine induces insignificant leukocytosis, lymphocytosis, heterophilia and monocytosis in broilers (Ismail, 2017; Mehwish et al., 2018).

Healthy broilers received cephradine in tested dose or received cephradine and vaccinated revealed insignificant heteropenia beside insignificant leukocytosis, lymphocytosis, esinophilia, basophilia and monocytosis allover experimental period. Cephalosporin causes destruction of leucocytes (Bang and Kammer, 1983). Cephradine induce insignificant leukocytopenia and heteropenia beside insignificant lymphocytosis, eosinophilia, basophilia and monocytosis (Borowski et al., 1985). Our results were in complete harmony with those reported by Oleas (2006) who found that ceftiofur sodium induced non-significant leukocytopenia and heteropenia after $3^{\text {rd }}$ day, $1^{\text {st }}$ and $2^{\text {nd }}$ week post vaccination. Insignificant leukocytopenia may due to effect of used drug in the granulopoeisis in bone marrow (Elisa, 1998). Broiler received another beta lactam (ampicillin) with Newcastle virus vaccine induced non-insignificant leukocytosis, heterophilia, lymphocytosis, monocytosis, eosinophilia and basophilia (Gamal, 2019). 
Healthy broilers vaccinated with Newcastle vaccine showed insignificant increase in phagocytic activity, phagocytic index and killing $\%$ all over the experimental periods post vaccination. Same changes in phagocytic activity were reported by Elsayed (1995) in broiler chickens vaccinated with Newcastle vaccine. Elevation in phagocytic activity, phagocytic index and killing \% might be due to activation of macrophages by production of lymphokines by $\mathrm{T}$ helper cells after their stimulation by Newcastle disease virus vaccine (Tizard, 1996). Vaccinated hens with Newcastle vaccine revealed increase in phagocytic activity and index (El-Sadek et al., 2008; Wang et al., 2015).

Healthy broilers received cephradine for 5 consecutive days and /or vaccinated with Newcastle vaccine either alone or together showed significant decrease in phagocytic activity, phagocytic index or killing\% at 1 st day beside nonsignificant decrease $10^{\text {th }}$ and $20^{\text {th }}$ day post vaccination. Cephalosporins reduced phagocytic functions of peripheral neutrophil-rich leukocytes and macrophages (Ohnishi et al., 1984). Cephradine induced decrease in phagocytic activity, phagocytic index or killing\% in broiler (Grec and Frei, 1984). Our results were reported previously by Vanholder et al., (1988) in broilers received cefquinome alone or with vaccine. Ceftifur sodium with Newcastle vaccine induces insignificant decrease in phagocytic activity, in phagocytic index and killing\% (Refaat, 1999). Our results were supported by those recorded by Ahmed (2015) who stated that cephalexin with vaccination induced significant decrease in phagoioytosis in rabbits. Our results were supported by Gamal (2019) mentioned that another beta lactam (ampicillin) with) with Newcastle virus vaccine induced non-significant increase in phagocytic activity and index throughout the experimental period post administration.

Healthy broilers vaccinated with Newcastle vaccine displayed insignificant increase in nitric oxide and lysozyme at $1^{\text {st }}$ day post vaccination and significant increase at 10 th and $20^{\text {th }}$ day post vaccination. Our results were observed by Vanholder et al., (1988) who reported that vaccination induced insignificant increase in lysozyme activity and nitric oxide. Same results were reported by El sayed (1995) who stated that broilers vaccinated with Newcastle vaccine revealed increase in lysozyme activity and nitric oxide. Same change in lysozyme activity and nitric oxide was reported by Hassanein, et al., (2001) in chicken vaccinated with Newcastle vaccine. Lysozyme activity and nitric oxide were increased post vaccination with Newcastle vaccines (Sami and Hamed, 2011).

Broilers received cephradine and /or vaccinated either alone or together displayed non-significant increase in lysozyme activity and nitric oxide allover experimental period. Our results were observed previously by Vanholder et al., (1988) who stated that non-significant increase in lysozyme activity and nitric oxide in broiler received cefquinome alone or with vaccine. Same changes in lysozyme activity and nitric oxide post using cephodizime (Auteri et al., 1990). Cefodizime stimulates nitric oxide production (Shin et al., 1996). Chemotherapeutic agent resulted in an increase in lysozyme activity andnitric oxide (Chin et al., 2000). Same changes in lysozyme activity and nitric oxide were observed previously by Gamal (2019) in broilers received ampicillinwith Newcastle virus vaccine.

Vaccinated broilers with Newcastle disease virus vaccine showed insignificant increase in total protein, total globulin, $\gamma$ globulin and HI at $1^{\text {st }}$ day post vaccination beside significant increase at $10^{\text {th }}$ and $20^{\text {th }}$ day post vaccination coupled with insignificant increase albumin, $\alpha$ globulin and non-significant decrease in serum $\beta$ globulin and $\mathrm{A} / \mathrm{G}$ ratio allover experimental periods post vaccination. Vaccination induced insignificant increase in $\alpha$ globulin beside non-significant decrease in $\beta$ globulin as well as significant increase in $\gamma$ globulin (Ahmed, 1991). The $\gamma$ globulin synthesis immunoglobulins (antibodies) which involved in defense mechanism and immunity of organism by opsonization and neutralization of antigens (Padlan, 1994). Similar results were reported by Elsayed (1995) who stated that broilers vaccinated with Newcastle vaccine revealed increase total protein, $\gamma$ globulin and decrease in serum $\beta$ globulin. Same changes in globulin fractions post vaccination were reported by Wang et al., (2015).

Healthy chickens received cephradine and /or vaccinated either alone or together showed insignificant increase in total protein, albumin, globulin, $\alpha, \beta$ and $\gamma$ globulin and $\mathrm{A} / \mathrm{G}$ ratio allover experimental period post vaccination. Broiler chickens received cephradine in therapeutic dose exerts insignificant increase in total protein, albumin, globulin, $\alpha, \beta$ and $\gamma$ globulin, $\mathrm{A} / \mathrm{G}$ ratioat $3^{\text {rd }}$ day, $1^{\text {st }}$ and $2^{\text {nd }}$ week post administration (Borowski et al., 1985). These results parallel with those obtained by Ahmed and Ismail(1998) who found that healthy broilers received ceftiofur sodium increase in total protein, albumin, total, $\alpha, \beta$ and $\gamma$ globulin. Our results was previously recorded by Refaat (1999) who stated that ceftifur sodium induced insignificant decrease in total and $\gamma$ globulin levels in broilers. Another beta lactam (ampicillin) with Newcastle virus vaccine induced insignificant decrease in total and $\gamma$ globulin levels in broilers (Gamal, 2019).

In the present study, it has been noticed that, healthy broilers vaccinated with Newcastle vaccine resulted insignificant increase in HI titers at $1^{\text {st }}$ day post vaccination and significant increase at $10^{\text {th }}$ and $20^{\text {th }}$ days post vaccination. Similar results were reported by Elsayed (1995) who stated that broilers vaccinated with Newcastle vaccine revealed increase HI titer within 6-10 days and peaks at 3-4 weeks post infection (Alexander, 1997). Same result was reported by Nasser (1998) and Abdu et al., (2012) who stated that Newcastle vaccine induced significant increase in $\mathrm{HI}$ titers after 2 nd week of vaccination and reach peak at day $21^{\text {st }}$ day post vaccination. Different doses of Newcastle vaccine induced significant increase in the HI titers (Wang, et al., 2015). Our results coincide with Abera (2018) who reported that $\mathrm{HI}$ titers increased at $10^{\text {th }}$ day post vaccination and remained up to 35 day post vaccination.

Healthy broiler chickens received tested dose of cephradine and /or vaccinated either alone or together showed significant decrease in HI titers at $1^{\text {st }}$ day post administration and insignificant decrease at $10^{\text {th }}$ and $20^{\text {th }}$ day post administration when compared with control broilers. Our results were observed previously by Vanholder et al., (1988) who reported that insignificant decrease in HI titers production in broiler received cefquinome alone or with another vaccine (Covexin). Same changes in HI titers were reported by Gamal (2019) in broiler received another beta lactam (ampicillin) with) with Newcastle vaccine.

Healthy broiler chickens vaccinated with Newcastle disease virus vaccine only revealed many pathological changes in liver as moderate degenerative changes in hepatocytes, mostly hydropic, moderate infiltration of the portal area with heterophiles and lymphocytes beside disorganization of the hepatic cells beside hypocellularity and atrophy of the glomeruli and degenerative changes in moderate number of the renal tubules coupled with changes in immune organ represented by mild deplestion of follicular lymphocytes in Bursa of fabricious. Spleen showing congestion of splenic sinusoids and depletion of some follicular lymphocytic. Same pathological change was reported by Nakamura et al., (2008) in broiler chickens vaccinated with Newcastle disease virus vaccine. Same lesion was observed in healthy broilers vaccinated with Newcastle disease virus vaccine (Kikuyasu et al., 2014). Our findings are nearly agreed with those recorded byAhmed et al., (2017) and Muhammad et al., (2018) who stated that Newcastle disease virus vaccine induced depletion of follicular lymphocytes in Bursa of fabricious and spleen.

Healthy broiler chickens received cephradine in tested dose showed mild round cells infiltration in the portal area and some hepatocytes showed hydropic degeneration beside normal glomeruli and renal tubules meanwhile, bursa of fabricious showed normal glandular epithelium and lymphatic follicles with mild depletion of the central follicular cells but spleen showed normal red and white pulp. Our findings are nearly agreed with those recorded by Tune et al., (1988) who stated that cephalosporin induce renal, cortical, mitochondrial and respiratory toxicity after exposure. Same lesion was observed in healthy broiler chickens received another cephalosporin (cefoperazone) (Shawky, 2007).

It was concluded that vaccination by Newcastle disease virus vaccine induced immuonostimulantbut cephradine provoked a remarkable immunosuppressive effect in broiler chickens. So vaccination during treatment by cephradine is not recommended. 

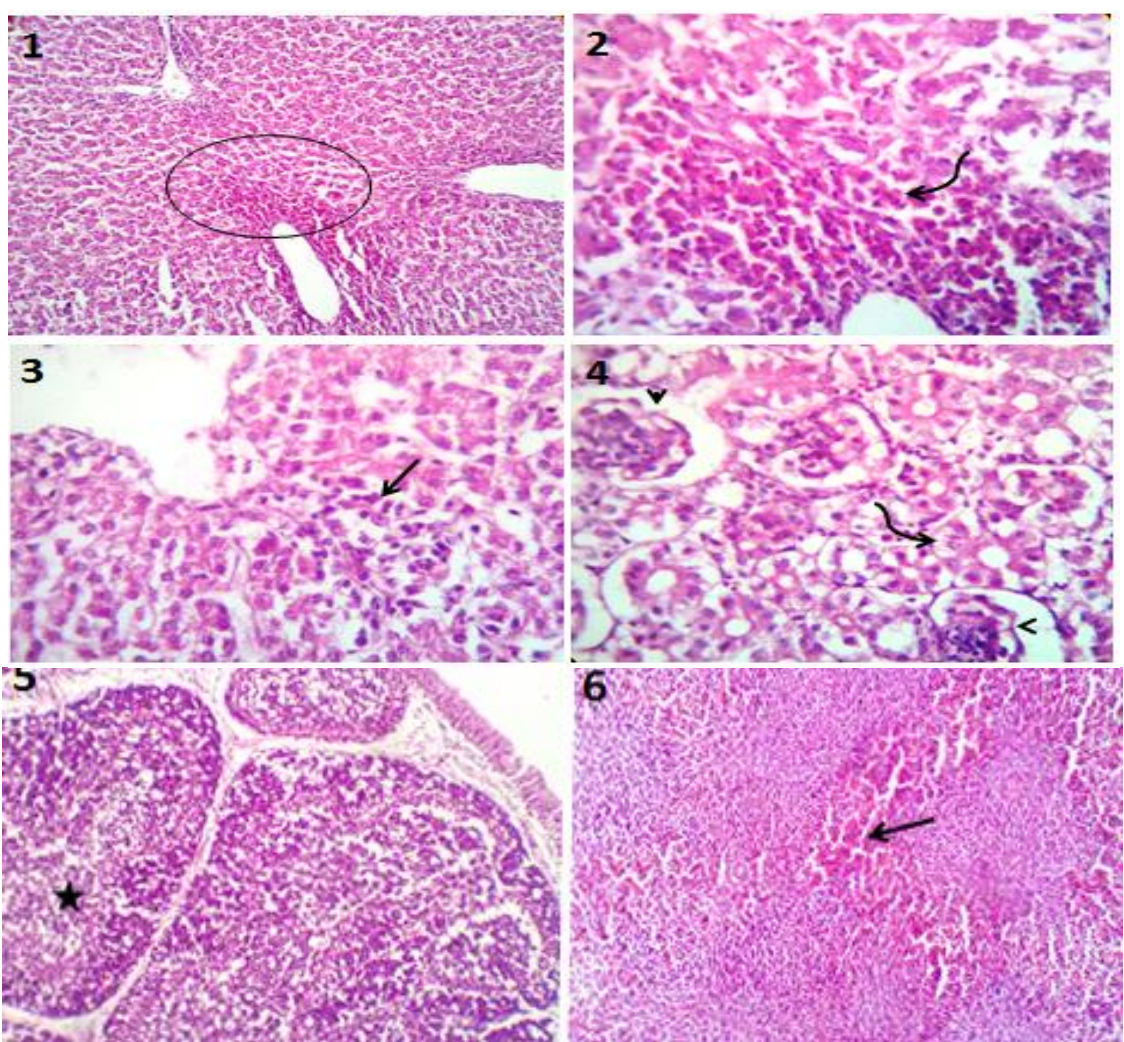

Fig. 1: Photomicrograph of Vaccinated Broiler with Newcastle Vaccine Revealed Liver (Fig 1,2,3) Showing Moderate Degenerative Changes in Hepatocytes, Mostly Hydropic,Moderate Infiltration of the Portal Area with Heterophiles (Curved Arrow) and Lymphocytes (Open Arrow) Beside Disorganization of the Hepatic Cells (Arrow Head). Kidney (Fig 4) Showing Hypocellularity and Atrophy of the Glomeruli (Arrow Heads) and Degenerative Changes in Amoderte No. of the Renal Tubules (Curved Arrow). Bursa (Fig 5) Showing Mild Deplestion of the Follicular Lymphocytes (Star). Spleen (Fig 6) Showing Congestion of Splenic Sinusoids (Open Arrow).
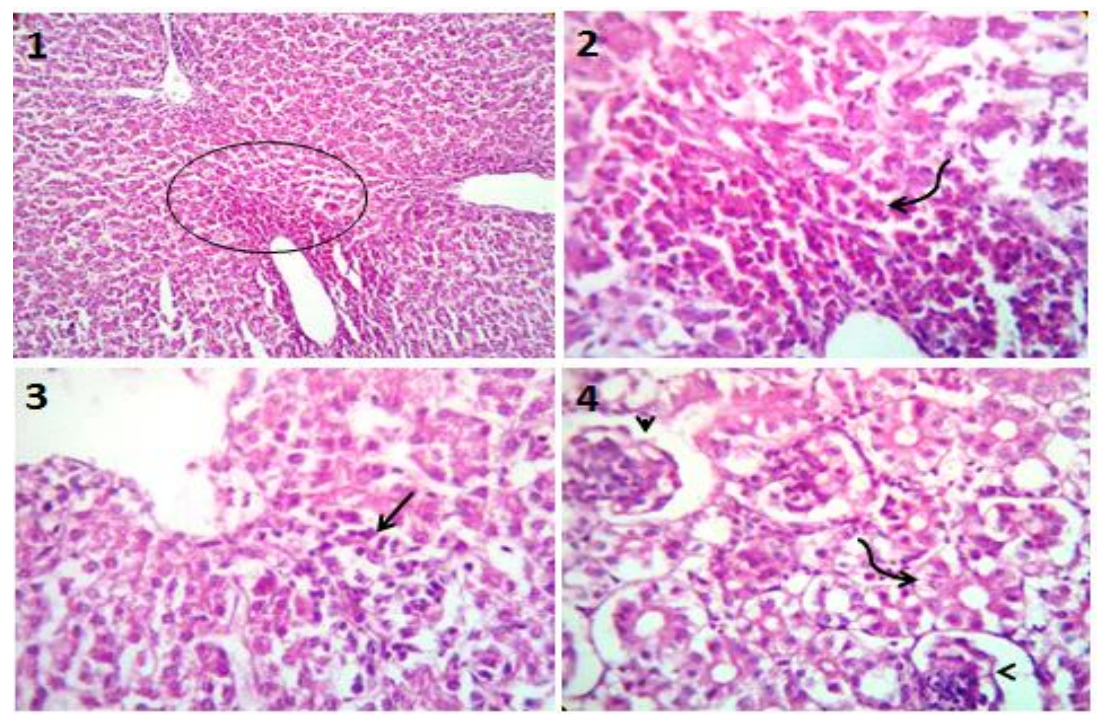

Fig. 2: Photomicrograph of Liver (Fig 1 and 2) Showing Portal Aggregations of Heterophils (Open Arrow) and Lymphocytes (Curved Arrow). Kidney (Fig 3 And 4) Showing Edema Beside Lymphocytic Infiltration Within Renal Papillae (Curved Arrow), Hydropic Degeneration In Glomerular Epithelium (Arrow Head) and Renal Tubular Epithelium (Open Arrow). 

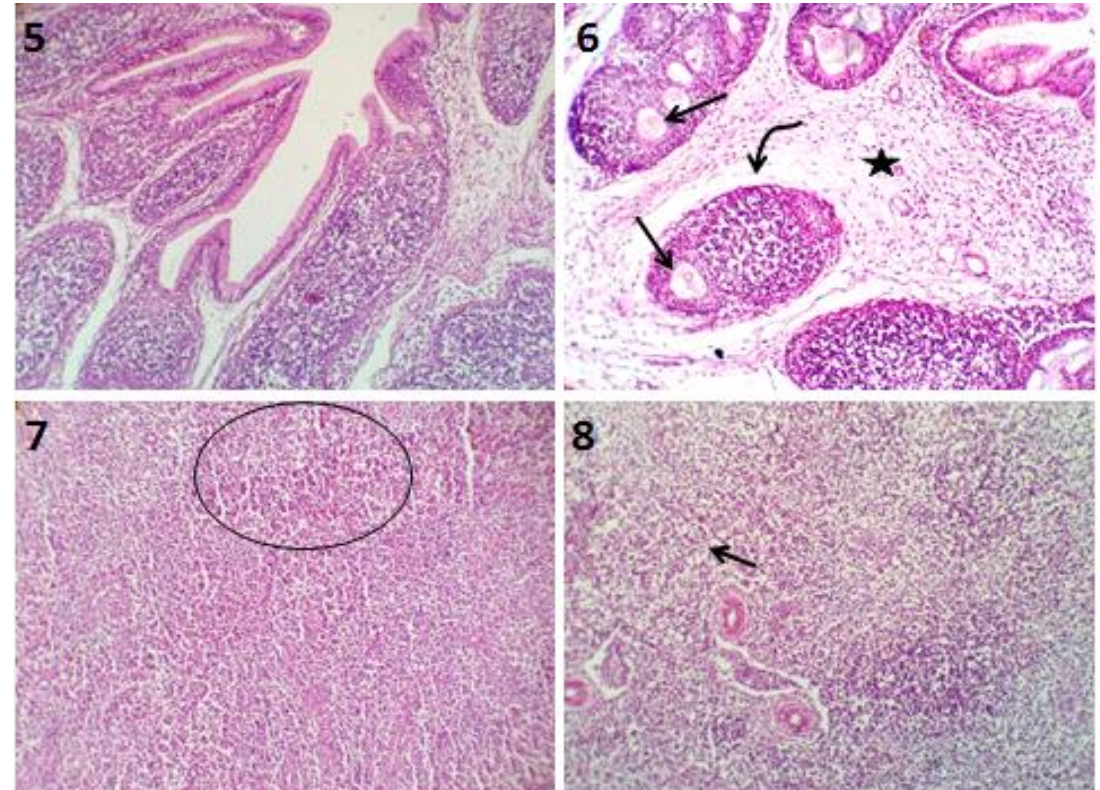

Fig. 3: Bursa (Fig 5) Showing Normal Mucosa and Bursal Follicles. Some Bursal Sections (Fig 6) Showing Atrophy of Some Follicles(Curved Arrow), Edema (Star) between Lymphocytic Follicles with Mild Cystic Changes Within Follicles (Open Arrows). Spleen (Fig 7, 8) Showing Mild Lymphocytic Depletion (Open Arrow) and Mild Infiltration of Hetereophiles in Splenic Sinusoids (Circle).

Table 1: Effect of Vaccination and Cephradine on Total and Differential Leucocytic Count of Broilers $(\mathrm{N}=5)$

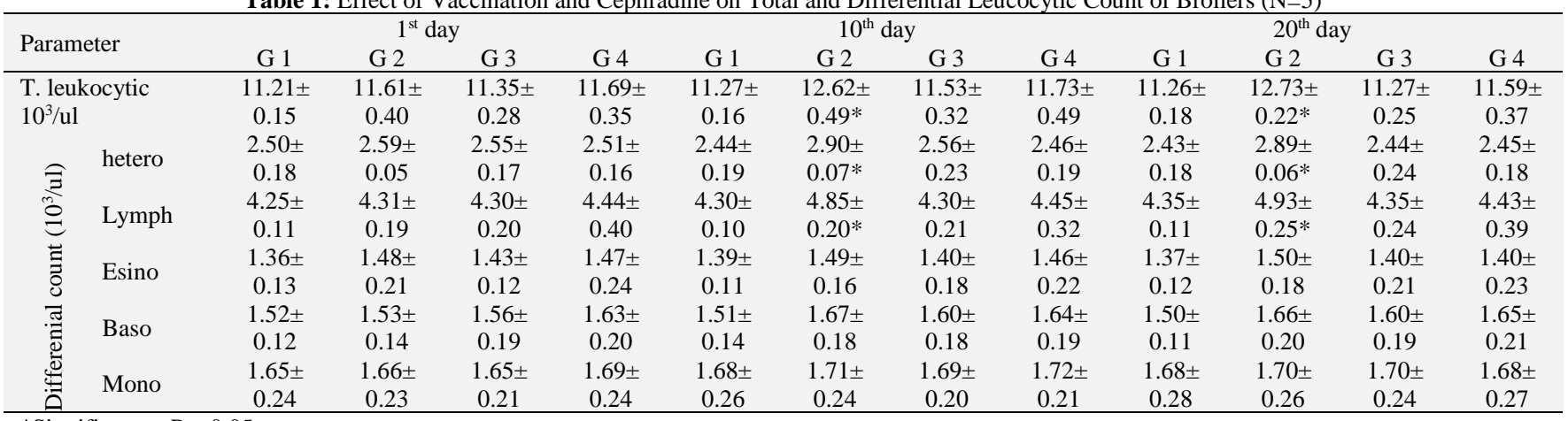

*Significant at $\mathrm{P}<0.05$.

Table 2: Effect of Vaccination and Cephradine on Phagocytic Activity\%, Phagocytic Index, Killing\% of Broilers (N=5)

\begin{tabular}{|c|c|c|c|c|c|c|c|c|c|c|c|c|}
\hline \multirow{2}{*}{ Parameter } & \multicolumn{4}{|c|}{$1^{\text {st }}$ day } & \multicolumn{4}{|c|}{$10^{\text {th }}$ day } & \multicolumn{4}{|c|}{$20^{\text {th }}$ day } \\
\hline & G 1 & $\mathrm{G} 2$ & G 3 & G 4 & G 1 & G 2 & G 3 & G 4 & G 1 & G 2 & G 3 & G 4 \\
\hline phagocytic & $40.13 \pm$ & $40.62 \pm$ & $38.83 \pm$ & $38.94 \pm$ & $40.15 \pm$ & $41.21 \pm$ & $38.58 \pm$ & $38.78 \pm$ & $40.1 \pm$ & $41.4 \pm$ & $38.95 \pm$ & $39.84 \pm$ \\
\hline activity\% & 0.54 & 0.31 & $0.4^{*}$ & $0.48 *$ & 0.41 & 0.48 & $0.22 *$ & $0.43^{*}$ & 0.59 & 0.85 & $0.39 *$ & 0.55 \\
\hline phagocytic & $4.86 \pm$ & $4.93 \pm$ & $3.92 \pm$ & $3.86 \pm$ & $4.86 \pm$ & $4.98 \pm$ & $3.92 \pm$ & $3.79 \pm$ & $4.80 \pm$ & $4.94 \pm$ & $3.92 \pm$ & $4.46 \pm$ \\
\hline index & 0.46 & 0.23 & $0.17 *$ & $0.29 *$ & 0.39 & 0.21 & $0.17 *$ & $0.25^{*}$ & 0.38 & 0.19 & $0.17 *$ & 0.19 \\
\hline & $76.39 \pm$ & $76.81 \pm$ & $74.44 \pm$ & $75.89 \pm$ & $76.43 \pm$ & $76.95 \pm$ & $74.65 \pm$ & $75.95 \pm$ & $76.7 \pm$ & $76.9 \pm$ & $75.05 \pm$ & $76.05 \pm$ \\
\hline killing\% & 0.23 & 0.49 & $0.61 *$ & 0.45 & 0.29 & 0.62 & $0.70 *$ & 0.39 & 0.26 & 0.23 & $0.42 *$ & 0.42 \\
\hline
\end{tabular}

*Significant at $\mathrm{P}<0.05$.

Table 3: Effect of Vaccination and Cephradine on Serum Nitric Oxide, Lysozyme Activity and HI Titreof Broilers (N=5)

\begin{tabular}{|c|c|c|c|c|c|c|c|c|c|c|c|c|}
\hline \multirow{2}{*}{ Parameter } & \multicolumn{4}{|c|}{$1^{\text {st }}$ day } & \multicolumn{4}{|c|}{$10^{\text {th }}$ day } & \multicolumn{4}{|c|}{$20^{\text {th }}$ day } \\
\hline & G 1 & G 2 & G 3 & G 4 & G 1 & $\mathrm{G} 2$ & G 3 & G 4 & G 1 & G 2 & G 3 & G 4 \\
\hline \multirow{4}{*}{$\begin{array}{l}\text { Nitric } \\
\text { oxide } \\
\text { lysozyme ac- } \\
\text { tivity }\end{array}$} & $26.16 \pm$ & $28.03 \pm$ & $26.24 \pm$ & $26.81 \pm$ & $27.11 \pm$ & $29.18 \pm$ & $27.22 \pm$ & $28.42 \pm$ & $27.1 \pm$ & $29.7 \pm$ & $27.19 \pm$ & $27.15 \pm$ \\
\hline & 0.56 & $0.41^{*}$ & 0.29 & $0.23 *$ & 0.39 & $0.37^{*}$ & 0.36 & $0.36^{*}$ & 0.43 & $0.4^{*}$ & 0.38 & 0.38 \\
\hline & $94.13 \pm$ & $96.20 \pm$ & $94.62 \pm$ & $99.88 \pm$ & $93.89 \pm$ & $99.32 \pm$ & $94.12 \pm$ & $95.12 \pm$ & $93.9 \pm$ & $99.48 \pm$ & $94.78 \pm$ & $95.10 \pm$ \\
\hline & 1.04 & 1.35 & 1.21 & $1.73 *$ & 1.10 & $1.61^{*}$ & 1.73 & $1.61 *$ & 1.12 & $1.7 *$ & 1.42 & 1.35 \\
\hline \multirow{2}{*}{ HI titre } & $3.13 \pm$ & $3.12 \pm$ & $1.98 \pm$ & $2.47 \pm$ & $3.23 \pm$ & $5.60 \pm$ & $2.92 \pm$ & $2.84 \pm$ & $3.26 \pm$ & $5.55 \pm$ & $2.98 \pm$ & $2.95 \pm$ \\
\hline & 0.14 & 0.12 & $0.39 *$ & $0.18 *$ & 0.32 & $0.39 * *$ & 0.23 & 0.22 & 0.25 & $0.9 * *$ & 0.25 & 0.23 \\
\hline
\end{tabular}

*Significant at $\mathrm{P}<0.05$. 
Table 4: Effect of Vaccination and Cephradine on Serum Total Protein and Protein Fractions of Broiler Chickens (N=5)

\begin{tabular}{|c|c|c|c|c|c|c|c|c|c|c|c|c|c|}
\hline \multirow{2}{*}{\multicolumn{2}{|c|}{ Parameter }} & \multicolumn{4}{|c|}{$1^{\text {st }}$ day } & \multicolumn{4}{|c|}{$10^{\text {th }}$ day } & \multicolumn{4}{|c|}{$20^{\text {th }}$ day } \\
\hline & & G 1 & G 2 & G 3 & G 4 & G 1 & G 2 & G 3 & G 4 & G1 & G 2 & G 3 & G 4 \\
\hline \multirow{2}{*}{\multicolumn{2}{|c|}{$\begin{array}{l}\text { T. protein } \\
(\mathrm{gm} / \mathrm{dl})\end{array}$}} & $5.57 \pm$ & $5.63 \pm$ & $5.59 \pm$ & $5.68 \pm$ & $5.54 \pm$ & $6.14 \pm$ & $5.90 \pm$ & $6.05 \pm$ & $5.58 \pm$ & $6.32 \pm$ & $5.81 \pm$ & $6.08 \pm$ \\
\hline & & 0.13 & 0.12 & 0.16 & 0.17 & 0.11 & $0.33^{*}$ & 0.19 & $0.16^{*}$ & 0.14 & $0.37 *$ & 0.18 & $0.1^{*}$ \\
\hline \multirow{8}{*}{ 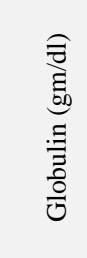 } & \multirow{2}{*}{$\alpha$} & $0.63 \pm$ & $0.69 \pm$ & $0.64 \pm$ & $0.65 \pm$ & $0.62 \pm$ & $0.68 \pm$ & $0.66 \pm$ & $0.74 \pm$ & $0.60 \pm$ & $0.66 \pm$ & $0.65 \pm$ & $0.69 \pm$ \\
\hline & & 0.13 & 0.14 & 0.14 & 0.15 & 0.15 & 0.12 & 0.12 & 0.17 & 0.13 & 0.14 & 0.13 & 0.12 \\
\hline & \multirow{2}{*}{$\beta$} & $0.85 \pm$ & $0.83 \pm$ & $0.84 \pm$ & $0.84 \pm$ & $0.86 \pm$ & $0.84 \pm$ & $0.85 \pm$ & $0.85 \pm$ & $0.85 \pm$ & $0.84 \pm$ & $0.84 \pm$ & $0.84 \pm$ \\
\hline & & 0.06 & 0.04 & 0.09 & 0.06 & 0.08 & 0.07 & 0.04 & 0.08 & 0.07 & 0.06 & 0.05 & 0.07 \\
\hline & \multirow[b]{2}{*}{$\gamma$} & $1.20 \pm$ & $1.31 \pm$ & $1.05 \pm$ & $1.28 \pm$ & $1.23 \pm$ & $1.41 \pm$ & $1.12 \pm$ & $1.48 \pm$ & $1.23 \pm$ & $1.38 \pm$ & $1.12 \pm$ & $1.42 \pm$ \\
\hline & & 0.04 & 0.09 & 0.07 & 0.07 & 0.05 & $0.04 *$ & 0.06 & $0.07 *$ & 0.03 & $0.05^{*}$ & 0.09 & $0.1^{*}$ \\
\hline & \multirow{2}{*}{ Total } & $2.68 \pm$ & $2.83 \pm$ & $2.67 \pm$ & $2.80 \pm$ & $2.69 \pm$ & $3.02 \pm$ & $2.71 \pm$ & $3.07 \pm$ & $2.73 \pm$ & $3.17 \pm$ & $2.72 \pm$ & $3.09 \pm$ \\
\hline & & 0.21 & 0.13 & 0.20 & 0.12 & 0.10 & $0.10^{*}$ & 0.10 & $0.11 *$ & 0.10 & $0.12 *$ & 0.14 & $0.1^{*}$ \\
\hline \multicolumn{2}{|l|}{$\mathrm{A} / \mathrm{G}$} & $1.08 \pm$ & $1.06 \pm$ & $1.08 \pm$ & $1.08 \pm$ & $1.05 \pm$ & $1.02 \pm$ & $1.08 \pm$ & $1.09 \pm$ & $1.06 \pm$ & $1.06 \pm$ & $1.06 \pm$ & $1.07 \pm$ \\
\hline \multicolumn{2}{|l|}{ Ratio } & 0.16 & 0.14 & 0.14 & 0.11 & 0.19 & 0.16 & 0.16 & 0.18 & 0.17 & 0.14 & 0.14 & 0.13 \\
\hline
\end{tabular}

*Significant at $\mathrm{P}<0.05$.

\section{References}

[1] Abdu, P.; Musa. U.; Joannis, T.; Saidu, L; Mera, U.; Salami, J. and Haruna, E. (2012): vaccination of chickens against Newcastle disease with Lasota and v4 vaccines using brans, ground grains and water as vehicles. J Vet Sci. 9: 1 - 10.

[2] Abera A (2018): adaptation of Newcastle disease virus vaccinal strain in vero cell line and evaluation of vaccine safety immunogenecityinchicken under laboratory condition. MSc Thesis Fac of Vet Med and Agri of Addis Ababa Uni.

[3] Aboubakr, M and Elbadawy M (2017) Bioavailability, pharmacokinetics and tissue residues of cephradine (Atocef Forte ${ }^{\circledR}$ ) in healthy and colisepticemic broiler chickens. International Journal of Pharmacology and Toxicology, 5 (1): 57-60. https://doi.org/10.14419/ijpt.v5i1.7428.

[4] Ahmed S.; El-Mandrawy, S. and Shimaa A. Ismail (2017) Selective Hematological, Biochemical and Pathological Alterations of Newcastle Virus in Naturally Infected and Vaccinated Broilers in Damietta Governorate of Egypt. Bulletin Vet Med. 74 (2): 139148https://doi.org/10.15835/buasvmcn-vm:0002.

[5] Ahmed, A and Ismail G (1998): Role of ceftiofur sodium in the control of p. multocida infection in chickens. ${ }^{\text {th }}$ Cong. Vet. Med. Zag. $632-645$.

[6] Ahmed, A. (1991): Studies on some epidemiological and immunological on tetanus. Ph.VSc Thesis presented to Fac. of Vet. Med., Alex Univ.

[7] Ahmed, S. (2015): Influence of cephalexin on Immuno status of vaccinated Rabbits. MVSci. Thesis, Dept. of Bird and Rabbit Diseases, Fac Vet Med. Zag. Univ.

[8] Alexander, D. (2009): Ecology and epidemiology of Newcastle disease. In: Avian Influenza and Newcastle Disease. A Field and Laboratory Manual, Capua I and Alexander DJ (eds.). Springer-Verlag, Milan, Italy, pp. 19-26.https://doi.org/10.1007/978-88-470-0826-7_2.

[9] Auteri, A.; Pusqui, A. and Diperr, T. (1990): Effect of cephodizime on immu-nological defects induced by surgical stress. Antimicobial Agent Chem. 34(9): 766-786.

[10] Bang, N. and Kammer, R. (1983): Hematologic complications associated with $\beta$-lactam antibiotics. Rev. Inf. Dis. S 380-S 393.https://doi.org/10.1093/clinids/5.Supplement_2.S380.

[11] Bogert, V and Kroon, A (1982): The influence of ceftafure sodium on immunological respo-nse. Drugs Exp. Clin. Res. 11(2): 8388.https://doi.org/10.3109/08820138209057744.

[12] Borowski J, Jaknik P, Talrczk J (1985): the influence of some cephalosporins on immunological response. Drug Exp Clin Res. 11:83-88.

[13] Chin, L.; Nugent, R. and Li, L. (2000): SNIP, a novel SNAP-25-interacting protein implicated in regulated exocytosis. J Biol Chem. 275:191200https://doi.org/10.1074/jbc.275.2.1191.

[14] Doumas, B.; Cartor, R.; Peers, T. and Schaffer, R. (1981): Acandidate reference method for determination of total protein in serum. Clin Chem. 27: 1642 .

[15] El sayed, M. F. (1995) influence of spectinomycin on the immunity of vaccinated chickens. MCs Thesis submitted to Fac. of Vet. Med. Alex. University.

[16] EL Sayed, M.G.; Aboubakr, M and Rabea, S (2016) Pharmacokinetics and tissue residues of cephradine in healthy and experimentally Salmonella entretidis infected broiler chickens. World Journal of Pharmacy and Pharmaceutical Sciences. 6 (6): 61-74.

[17] El-Hewaity M, Abd $\quad$ El Latif A, Soliman A, Aboubakr $\quad$ M. $\quad$ (2014) tive Pharmacokinetics of Cefquinome (Cobactan 2.5\%) following RepeatedIntramuscular Administrations in Sheep and Goats. J Vet Med. 2014:949642. https://doi.org/10.1155/2014/949642.

[18] Elisa, A.A. (1998): Clinicopathologic studies on some antidiarrhoeal drugs in rabbits. MVSc. Thesis, Faculty of Vet. Med., Zagazig Univ.

[19] El-Sadek, A.; Badr, Y.; Lotfy, O. and Ramadan, H. (2008): Evaluation of maternal antibodies from vaccinated hens in protection of hatched chicks from e. coli infection. $9^{\text {th }}$ Vet. Med. Zag. Conf. pp: 515-524.

[20] Filali, E.; Bell, J.; El-Houadfi, M. and Huggins, M. (1988): Comparative Immunology Microbiology and Inf. Dis. 11(2): 121124.https://doi.org/10.1016/0147-9571(88)90027-6.

[21] Gamal A. (2019): Untraditional treatments for controlling Clostridial infection in broiler chickens. PHD Thesis Submitted to Zag Uni (Pharmacology).

[22] Grec, V. and Frei, P. (1984): Effect of amoxicillin on function of granulocytes tested in vitro and on chemotaxis of granulocytes from rabbits given two antibiotics. Inflamation J. 8: 417-427.https://doi.org/10.1007/BF00918217.

[23] Hassanein, Z.; Mona, M. and Hassan, M. (2001): Nature of immune suppress-ion induced by E. coli infection in vaccinated chickens. J. Egypt. Vet. Med. Assoc. 61: 79-89

[24] Henry, R.; Cannon, D and Winkelman, J. (1974): Clinical Chemistry Principals and techniques p 437 - 440, Harper and Row, Hagerstown.

[25] Ismail, T. (2017): Biochemical and hematological studies on the effect of Neem (Azadirachtaindica) leaves aqueous extract on Newcastle vaccine and infection in broiler chickens. Int J Recent Sci Res. 8(3): 15876-15884. https://doi.org/10.24327/ijrsr.2017.0803.0002.

[26] Jain, N.C. (1986): Schalm's veterinary Haematology 4th Ed., pp. 55-96, Lee and Febiger, Philadelphia, U.S.A.

[27] James, E. (1993): Martindale, the extra pharmacopoeia, Royal Pharmaceut-ical Society, London. $30^{\text {th }}$ Ed.

[28] Kikuyasu, N.; ,Mitsuru , I.;Toshiki, N.; AYu, Y.;Manabu, Y.; Masaji, M. and Kunitoshi, I. (2014): Pathogenesis of Newcastle Disease in Vaccinated Chickens: Pathogenicity of Isolated Virus and Vaccine Effect on Challenge of Its Virus. J Vet Med Sci. 2014 Jan; 76(1): 31-36. https://doi.org/10.1292/jvms.13-0284.

[29] Lillie, R. D. and Fulman, H. M. (1976): Histopathological technique and practical histopathology. The lalauiston division, New York and London Acad. Sci. 111:789-792.

[30] Mehwish, M., Muhammad, S. and Hamidullah, H. (2018): Effects of Newcastle Disease Virus on Different Haematological Parameters in Broilers. Advances Animal Vet Sci. 6(4): 231- 129https://doi.org/10.17582/journal.aavs/2018/6.4.183.186.

[31] Moreno, E; Ruiz, A and Lorente, F (2007): Selective Immediate Hyper-sensitivity to cefepime.JInvestig. Allergol Clin. Immu. 17 (1): $52-54$. 
[32] Muhammad B.; Khatijah, Y.; Aini, I.; Mohd, H.; Ben, P. and Abdul Rahman O. (2018): Diagnostic and Vaccination Approaches for Newcastle Disease Virus in Poultry: The Current and Emerging Perspectives. Bio Med Res. Int. 18(2): 138-149.https://doi.org/10.1155/2018/7278459.

[33] Nakamura K., Ohtsu N., Nakamura T., Yamamoto Y., Yamada M., Mase M., Imai K. (2008): Pathologic and immunohistochemical studies of Newcastle disease (ND) in broiler chickens vaccinated with ND: severe nonpurulent encephalitis and necrotizing pancreatitis. Vet. Pathol. 45: 928933https://doi.org/10.1354/vp.45-6-928.

[34] Nasser M (1998): Oral Newcastle disease vaccination trials and studies of Newcastle disease in Ethiopia, M.Sc Thesis, Freie Universität.

[35] Ohnishi, H.;Inaba, H.; Mochizuki, H. and Kosuzume, H. (1984): Mechanism of action of AC-1370 on phagocyte functions. Anti. Agents Chemoth. 25: 88-92.https://doi.org/10.1128/AAC.25.1.88.

[36] Oleas H. (2006): Efficacy of ofloxacin and ceftiofur sodium in chickens Ph.V.Sc. Thesis Forensic Med, presented to Fac. of Vet. Med., Zag University.

[37] Padlan, E. (1994): Anatomy of antibody molecule. Mol. Immunolog. 31(3): 69-70. https://doi.org/10.1016/0161-5890(94)90001-9.

[38] Petrie, A. and Watson, P. (1999): "Statistics for Veterinary and Animal Science. "1st Ed. PP. 90 - 99. The Black well Sc. Ltd. United Kingdom.

[39] Ramadan, A and Attia, E (2003): Natural killing molecules in cervical mucus of buffaloes during estrous cycle. $7^{\text {th }}$ Sci. Cong. Egypt. Soci. for cattle dise., Assiut.

[40] Refaat, S. (2009): Effect of ceftiofur sodium (Excenel) on immune response of vaccinated chickens. PHD Theses submitted to Fac of Vet Med.Zag Uni.

[41] Richard, K. and Merle, A. (1984): "New Dimenions in Antimicrobial Therapy“Churehil Livingstone-New York, Edinburgh London and Melbourne.

[42] Rouse, B; Babiuk, Land Henson, P (1980): Neutrophils in antiviral inhibition of virus replication mediator produced by bovine neutrophil. J. Inf. Dis. 141(2): 3-9.https://doi.org/10.1093/infdis/141.2.223.

[43] Saif, Y. (2008): Disease of poultry $12^{\text {th }}$ Edition.

[44] Sami, A. and Hamed, A (2011): Impact of synbiotic on immune response of broilers against NDV vaccine. Global J Biot. 6 (4): $186-191$.

[45] Schltz, L. (1987): Methods in Clinical Chemistry. CV Mosby cost Lous. Pp: $42-46$.

[46] Shah, I. (2009): Histochemical studies on paratuberculosis in goats. M.Sc. Thesis, Fac. of Postgraduate, Sher-e-Kashmir Uni of Agri Sci and Technology, Kashmir.

[47] Shalaby, M. (1989): Immunosuppressive and their effect on the immune system of poultry. First Annual Report.Cav.MI 354.

[48] Shawky, N. (2007): Antibacterial efficacy of cefoperazone and its combination with sulbactam in chickens Master Thesis submitted to Fac. Of Vet Sic. Zagazig University (Veterinary Pharmacology).

[49] Shin, W.; Min, C. and Kang, M. (1996): In-vitro effects of cefodizime on leucocyte functions and colony formation from granulocyte-monocyte progenit-ors. J. of anti. Chemo. 37: 93-103.https://doi.org/10.1093/jac/37.1.93.

[50] Tharwat, I.; El Nabarawy, E.; Aly, S. and Hassan, A. (2013): Effect of apramycin on pathological, hematological and biochemical changes in turkey infected with coli-septicemia. Zag. Vet. Med. J. 41(1)124-136.https://doi.org/10.1155/2013/153427.

[51] Thomson,T.; Quay, J. and Webber, J. (1984): Cephalosporin group of antimicrobial drugs.J. Am.Vet. Med. Ass. $185(10): 1109-1114$.

[52] Tizard, I. (1996): Veterinary immunology. An Introduction. 5th Ed., WB Saunders Comp, A division of Harcourt Comp, London, Toronto, Sedny, Tokyo.

[53] Tune, B.; Sibley, R. and Hsu, C. (1988): The mitochondrial respiratory toxicity of cephalosporin antibiotics. An inhibitory effect on substrate uptake. J. Pharmacol. Exp. Ther. 245 (3): 1054-1059.

[54] Vanholder, R.; Landschoot, N.; Agrosa, E. and Ringoir, S (1988): Cefodizime: A new Cephalosporin with apparent immune stimulating properties in chronic renal failure .Nephrol. Dial. Transplant. 2:221-224.

[55] Wang X, Zhou Q, Shen J, Yao J, Yang X (2015): Effect of Newcastle disease vaccine immunization on growth performance, plasma variables and immune response of broilers. J Animal Sci Biotec, 6(1):20. https://doi.org/10.1186/s40104-015-0019-y.

[56] Wilson, A. and Gisvold, T. (1982): Textbook of organic medicinal and pharmaceutical chemistry. 8th edition,

[57] Woldehiwet, Z. and Rowan, T. (1990): Some observations on effects of age of calves on phagocytosis and killing of Staph aureus by polymorph nuclear leucocytes. Br. Vet. J. 146: 165 - 170.https://doi.org/10.1016/0007-1935(90)90009-R. 